\title{
The Teacher as Leader: Effect of Teaching Behaviors on Class Community and Agreement
}

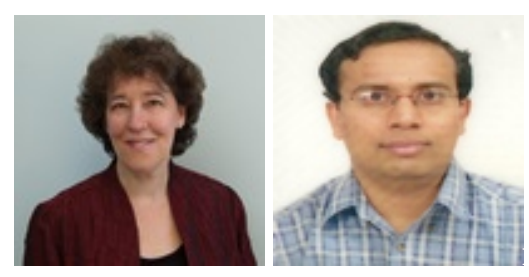

Beth Rubin ${ }^{1}$ and Ronald Fernandes ${ }^{2}$

1Miami University, USA, ${ }^{2}$ DePaul University, USA

\section{Abstract}

This article examines the effects of teaching behaviors in online university classes, focusing on the agreement among class members. Literature on group leaders' effects on group agreement about workplace climate is reviewed. Hypotheses are generated about the effects that teachers of online courses, as class leaders, have on both the level and agreement about the community of inquiry. They are tested with a sample of 874 students in 126 online courses. The aggregate class level and strength of agreement about the teaching presence have significant effects on the level and agreement about cognitive presence and social presence. Although the aggregate levels and agreement about community of inquiry are related, different patterns emerge.

The paper explores the interaction effects of level and agreement, finding that in classes with high levels of teaching presence, the higher the agreement about teaching presence, the higher the agreement about cognitive and social presence especially for classes reporting stronger levels of cognitive and social presence. In classes with lower levels of teaching presence, agreement has a different effect.

Keywords : Community of inquiry; online learning; class agreement; aggregate perceptions; class leadership; social presence; teaching presence; cognitive presence 


\section{Introduction}

Teachers of online classes lead classes to create a community of inquiry (CoI) wherein participants interact to jointly construct knowledge (Anderson, Rourke, Garrison, \& Archer, 2001; Garrison, Anderson, \& Archer, 2000, 2010a). One unexplored element in this process is the strength of agreement among students in the class, and the effect that communally held perceptions of teaching presence have on social and cognitive presence; this study addresses that gap, holding that both the levels of teaching, social, and cognitive presence and the extent to which students agree or disagree about these levels are important aspects of the learning environment.

\section{Literature Review}

The CoI framework views online classes as socially constructed virtual communities that consist of three major elements: teaching presence, social presence, and cognitive presence (Garrison et al., 2000; Rourke, Anderson, Garrison, \&Archer, 1999). Teaching presence refers to instructors' support for the class and learning through designing course materials and learning activities, guiding discussion, administering the course, and providing feedback (Anderson et al., 2001; Arbaugh, 2007; Garrison \& ClevelandInnes, 2005). Social presence involves the development of emotional connections, trusting relationships, and identification among members of the online class (Richardson \& Swan, 2003; Swan \& Shih, 2005), while cognitive presence is the extent to which students construct meaning that is transferable to new situations, involving the learning activities of practical inquiry: facing a triggering event, exploring concepts, integrating and evaluating possibilities, and attaining resolution (Kanuka \& Garrison, 2004). The teacher's design of the work done in a class, and leadership of students through the learning process, parallel the processes used by group leaders to support both collegial interaction and individual performance in work organizations (Luke, 1997; Pounder, 2008). Both leaders and teachers set and reinforce group climate, set expectations, assess work, and provide support and feedback (Gillespie \& Parry, 2009; Shea, Li, Swan, \& Pickett, 2005). While there are certainly differences between teaching a class and leading a work group, including the time frame and the significance of rewards, there are many similarities.

\section{Leaders and Agreement Among Group Members}

When leaders are more effective in guiding and supporting group members, they can create stronger agreement among the group members in their perceptions of the climate (Bliese \& Halverson, 1998; Feinberg, Ostroff, \& Burke, 2005). The dispersion or agreement about climate perceptions held by organizational group members have similar effects to the dispersion or agreement among university class members; for example, the effects of the amount and the agreement about satisfaction among members of a class team on absenteeism are similar to the effects of satisfaction with a work group (Dineen, Noe, Shaw, Duffy, \& Wiethoff, 2007). Therefore, findings on the 
effects of leadership on group agreement and outcomes may be applicable to the effects of teaching on student agreement and outcomes.

The behavior of group leaders affects both the nature and the agreement among group members about the work, and these shared views frame members' understanding of the work environment and predict their actions in many ways (Dragoni, 2005; Feinberg et al., 2005; Schneider \& Reichers, 1983). For example the behavior of group leaders strongly affects the group members' shared perceptions of appropriate behavior about safety, which predict accident rates (Zohar \& Luria, 2005, 2010). Both the average level and the agreement about group leaders' emphasis on high quality service predict customers' perceptions of the quality of service provided (Schneider, Salvaggio, \& Subirats, 2002). The strength of group consensus on leadership and peer relations predicts psychological well-being of group members (Bliese \& Halverson, 1998).

Employees who have closer relationships with their leaders, characterized by better communication and more trust, report a more positive work climate, including factors such as the clarity and structuring of work, ability to make decisions, teamwork and intergroup cooperation, and support from management (Ford \& Seers, 2006). Such employees also have higher levels of agreement with one another, and more agreement with their leaders' perceptions about the workplace (Kozlowski \& Doherty, 1989).

Leaders who are transformational, developing trusting and open relationships with their employees, create both more positive group climates and greater agreement among group members about the climate (Cole \& Bedeian, 2007; Feinberg et al., 2005; Zohar \& Luria, 2010). Key transformational leadership behaviors that produce a shared and positive climate include behaviors that parallel teaching presence, including communicating group goals (Cole, Bedeian, \& Bruch, 2011a; Schneider, White, \& Paul, 1998; Zohar \& Luria, 2005) and providing information (González-Romá, Peiró, \& Tordera, 2002).

Similarly, instructors lead classes using different approaches, some more transactional and some more transformational (Pounder, 2008). Students interact both for social purposes and to complete their tasks. The interaction and trust among class members are reflected in the CoI concept of social presence, while the relationship, active guidance, and support from the teacher in the online learning experience are reflected in teaching presence.

\section{Class Community: Class Level Versus Agreement}

The CoI reflects interaction among online class members, which influences the individual learning experience (Shea et al., 2010). As such, it can be measured by examining the aggregated descriptions of class members. Prior research has aggregated student perceptions of traditional classroom environments, conditioned on empirical evidence that class members share common views of the teacher or class environment, and that perceptions distinguish classes from one another (Lüdtke, Trautwein, Kunter, 
\& Baumert, 2006). Aggregated student perceptions have been viewed as highly valid measures of teacher behavior and the class environment (Kunter, Baumert, \& Köller, 2007).

However, few studies have considered the effect of agreement among students in online classes. The aggregated class level and agreement, although often related, reflect very different phenomena, and very different patterns can emerge in students' descriptions of their classes. For example, if the average class rating on teacher presence is a three on a scale of one to five, it might be concluded that the teacher had an average level of teaching presence. However, this would only be the case if there is agreement within the group, which would produce very low standard deviations. Alternatively, there might be some students who view the teaching behaviors as excellent and others who do not; the most extreme differences of opinion would produce strongly bimodal distributions, and a very high standard deviation. Table 1 illustrates some possible distributions that produce an average score of 4.0, along with the corresponding standard deviations. Each distribution indicates a different strength of community in the class.

Table 1

Different Group Distributions that Produce a Mean Score of 4.0

\begin{tabular}{|c|c|c|c|c|c|c|c|}
\hline Group & $\mathbf{1}$ & $\mathbf{2}$ & $\mathbf{3}$ & $\mathbf{4}$ & $\mathbf{5}$ & Mean & SD \\
\hline 1 & $0 \%$ & $0 \%$ & $0 \%$ & $100 \%$ & $0 \%$ & 4 & 0.00 \\
\hline 2 & $0 \%$ & $0 \%$ & $50 \%$ & $0 \%$ & $50 \%$ & 4 & 1.05 \\
\hline 3 & $0 \%$ & $0 \%$ & $20 \%$ & $60 \%$ & $20 \%$ & 4 & 0.67 \\
\hline 4 & $0 \%$ & $0 \%$ & $30 \%$ & $40 \%$ & $30 \%$ & 4 & 0.82 \\
\hline 5 & $0 \%$ & $20 \%$ & $0 \%$ & $40 \%$ & $40 \%$ & 4 & 1.15 \\
\hline 7 & $20 \%$ & $0 \%$ & $0 \%$ & $20 \%$ & $60 \%$ & 4 & 1.63 \\
\hline
\end{tabular}

Clearly the optimal course reflects both a high average score and strong agreement; in such a case, a strong community has been developed and the class agrees that it is positive. It must be noted that, because of restriction of range, the level and agreement of group-level variables are likely to be correlated toward the extremes. In order to have an average score of either a five or a one on a five-point scale, there must be complete agreement, while aggregated scores toward the center of a scale may reflect higher or lower degrees of agreement (Cole, Bedeian, Hirschfeld, \& Vogel, 2011b; Lindell \& Brandt, 2000). Therefore the interaction between the agreement and average level of presence should be considered when examining the community in online courses. Research on organizational climate has often found such interaction effects (Lindell \& 
Brandt, 2000), particularly when examining the group level and agreement about the leader's behavior affecting group outcomes (Cole et al., 2011a; Zohar \& Luria, 2010).

Agreement about the learning environment in online courses is fundamentally different from levels. Traditionally, research on online courses considers only the level of the learning community - the individual scores that students report on the measures of teaching, social, and cognitive presence. The agreement among class members, or the strength of the community, has not been extensively examined, and is likely to have more complex relationships with various aspects of the learning environment. High agreement does not imply high levels, as class members may agree about low levels of a variable. To understand the nature of the learning community in an online class, both the aggregate levels and the agreement at any given level should be considered.

\section{The Effect of Teaching Presence Levels and Agreement on Community}

When teachers design application-oriented learning activities, clearly describe their expectations, guide students through exploring differences of opinion, focus the class and provide helpful feedback, students develop deeper learning and can integrate ideas, solve problems, and apply concepts in the future (Akyol \& Garrison, 2011; Bangert, 2008; Shea et al., 2005). This careful design of courses and engaged, student-focused teaching creates more clarity about learning activities, and supports active discourse and critical analysis that create higher levels of cognitive presence. It has already been established that individual perceptions of teaching presence predict individual perceptions of cognitive presence (Garrison, Cleveland-Innes, \& Fung, 2010b; J oo, Lim, \& Kim, 2011; Shea \& Bidjerano, 2009a, 2009b). This study extends this research to the class level, proposing that the aggregate, shared perceptions of teaching presence levels, and agreement about them, create aggregate perceptions of cognitive presence.

Student-oriented teaching that involves clear specification of tasks, encouragement, feedback, guidance, and communication is parallel to transformational leadership. In online courses, teaching behaviors include activities such as providing specific assignments, posting regular announcements, actively guiding discussion, and providing public and private feedback. Active teachers probe for deeper understanding, contrast student perceptions to uncover complexities, and guide students to engage with one another to consider alternative perspectives and applications (Bangert, 2008). This will draw students into higher levels of integration and more application of concepts, producing higher levels of cognitive presence for the class as a whole. Most of these behaviors are public, and students share perceptions through comments in online discussions about instructor behavior and course design. Higher levels of teaching presence and greater agreement among class members about the teaching behaviors are likely to lead to higher levels of cognitive presence.

Hypothesis 1: The higher the aggregate level of teaching presence and agreement among students in an online class, the higher the aggregate level of cognitive presence. 
Teachers can design courses to support student interaction through discussions, group assignments, and other learning activities. They can set requirements for discussion responses or integrate task and social activities, and create areas for informal interactions (Ke, 2010; Rovai, 2007; Swan, 2004). Teachers can also actively facilitate courses to support student interaction by posting comments and questions that encourage students to communicate and by grading students based on their engagement with others (Rovai, 2007; Shea et al., 2005). They can model open communication and self-disclosure, and reward students for building a connected community.

Teaching that is based on open relationships, clarity, and communication, like transformational leadership, should strengthen the relationships among the members of an online class. This should create a stronger learning community, with high aggregate class levels of social presence and agreement about those levels, which reflect trust, openness, and identification with the class. The causal impact of teaching presence on social presence has already been empirically supported for individual perceptions (Garrison et al., 2010b; Shea \& Bidjerano, 2009b), both in terms of designing courses to support discussion (Akyol \& Garrison, 2011; Ke, 2010) and directed facilitation and instruction (J oo et al., 2011; Kim, Kwon, \& Cho, 2011). The aggregate levels of teaching presence for a class, and agreement among students, should be associated with high levels of social presence.

Hypothesis 2: The higher the aggregate level of teaching presence and agreement among students in an online class, the higher the aggregate level of social presence.

Active, engaged, and open class leadership and the resulting closer relationships should lead to more interaction among class members with their instructor, as well as with one another and the course content. This should produce both more positive and more closely shared views among class members about the teacher's behavior. When classes encourage students to engage in deep learning, both the aggregate level of teaching and the agreement among students about those behaviors should predict stronger agreement among students about cognitive presence. The strength of the learning community, reflected in the agreement among students, would independently reinforce all its elements including communal critique and understanding; in these engaged classes, agreement about teaching presence begets agreement about cognitive presence.

However, this would only occur when a strong community of inquiry exists. Faculty may structure the class well, administer it effectively, and respond to students without guiding deep understanding, critical inquiry, and application (Richardson \& Ice, 2010); they can engage in many teaching behaviors but not support higher levels of cognitive presence (Rourke \& Kanuka, 2007). As a result, some students may individually wrestle with concepts, integrate and apply information, but they would not do this work together, creating lower levels of agreement about cognitive presence. In addition, teachers may support critical analysis and application for some students more than others through private feedback. On the other hand, some students may choose to not 
participate in course activities. Both differentiated teaching support and student variation in engagement would produce less agreement about cognitive presence.

Hypothesis 3: The higher the aggregate level of teaching presence and agreement among students in an online class at a given level, the higher the agreement about cognitive presence.

Similar phenomena can occur for social presence. In some classes, the students are closely connected; they collaborate, share ideas, trust one another, and identify with the class. Typically, such active and supportive learning communities are created by teachers who design effective learning activities, guide discussion, and encourage discourse and exploration. While there are certainly individual differences among students, teachers who engage in many active teaching behaviors and treat students fairly should create a stronger virtual community, wherein students are more likely to communicate their perceptions and reactions, develop trust and cohesiveness, and identify with the class. Sharing these perceptions should lead to greater agreement among students about social presence.

When teachers do not demonstrate strong teaching presence, a different dynamic is produced. Social presence should be more variable, as there is less of a unifying and guiding force supporting interaction. Some students communicate and share with their peers, while others may engage in less communication due to limitations of time, personal preference, confidence, or comfort with technology-mediated communication. The positive effect of agreement about teaching presence should only exist in classes where teachers engage in active direction, and students respond positively by jointly sustaining a learning community through their interaction. In classes that have lower aggregate levels of social presence, agreement among the students about teaching presence would indicate that they all perceive a lack of active support and/or lack of clear course structure. Disagreement, on the other hand, means that some students report active support while others do not. When social and teaching presence levels are low, high agreement about teaching presence indicates consistently limited active facilitation, likely leading to low levels and agreement about social presence.

Hypothesis 4: The higher the aggregate level of teaching presence and agreement among students in an online class at a given level, the higher the agreement about social presence. 


\section{Methodology}

\section{Sample}

Data were collected over the course of three years from 126 fully online sections in five colleges in a large Midwestern university. There were 874 student responses, although some responded more than once if they took multiple classes that participated in the study.

Data were collected from graduate courses in the Schools of Public Service (4\% of the classes), Commerce (0.8\%), and Education (4.8\%) as well as two undergraduate programs in Computer Science (0.8\%) and an interdisciplinary school for adult students (89.7\%). Most (90.5\%) were undergraduate courses. Students ranged from 19 to 69 years old, with an average of 35.5. Nearly two-thirds, or $64.7 \%$, were female and $35.3 \%$ were male. The vast majority, $83.3 \%$, had taken prior online courses, with a mean response of between four and five prior courses.

\section{Data Collection Procedures and Measures}

CoI was measured by the standard validated questionnaire (Arbaugh, 2007; Swan et al., 2008). Participation in the study was voluntary for teachers and for students; response rates averaged $35.5 \%$ per class, and the average number of participants per class was 6.9. Coefficient alphas were .95 for the 13-item Teaching Presence scale, .89 for the 9item Social Presence scale, and .93 for the 12-item Cognitive Presence scale.

Class scores for teaching presence ranged from 3.32 to 5.00, with a mean of 4.20; social presence scores ranged from 3.11 to 4.78 , with a mean of 4.02; and cognitive presence scores ranged from 3.49 to 5.0, with a mean of 4.15. This restriction of range indicates that no classes had low levels on these variables. Dummy variables were created to distinguish higher from lower levels. Values between 4.0 and 5.0 on each scale were coded as 1, while those between 3.0 and 4.0 were coded as 0 . Three control variables were also included in the study: student gender, age, and the number of previous online courses taken. The number of prior online courses was measured by ten options ranging from "none" to "nine or more." Control variables were aggregated across each class to represent the overall group (Conway \& Briner, 2012; Dineen et al., 2007) by calculating the percentage of the class that was female, the average student age, and the average number of prior online courses taken. It should be noted that the average number of online classes may be underestimated, because the actual highest number of online courses taken may be higher than nine.

\section{Data Aggregation}

In order to determine whether there is sufficient within-class agreement and betweenclass differentiation to aggregate within classes, there must be evidence that 1) students 
agree sufficiently within classes to have some degree of confidence that a class-level CoI exists; and 2) classes differ from one another on their views of the CoI (LeBreton \& Senter, 2008; Lüdtke et al., 2006). The intra-class correlation 2 (ICC(2)) was calculated for teaching presence, social presence, and cognitive presence to measure within-class agreement, and intra-class correlation 1 (ICC(1)) was calculated as an index of betweenclass differences (Biemann, Cole, \& Voelpel, 2012; Conway \& Briner, 2012; Glisson \& J ames, 2002; LeBreton \& Senter, 2008; Lüdtke et al., 2006; Zohar \& Luria, 2010).

The ICC(2) was 0.82 for social presence and teaching presence, and 0.88 for cognitive presence, all far exceeding the .70 minimum and indicating within-class agreement. ICC(1) was .39 with an F-ratio of 5.44 ( $p<.001)$ for social presence; 0.40 with an Fratio of $5.60(\mathrm{p}<.001)$ for teaching presence; and 0.39 with an F-ratio of $5.45(\mathrm{p}<$ .001). The F-ratios were all highly significant, and the ICC(1) values were far above the minimum effect size of .05 (Biemann et al., 2012; LeBreton \& Senter, 2008). This indicated that classes differed significantly in teaching presence, social presence, and cognitive presence.

Class-level variables were created to measure 1) the amount of class-level on teaching presence, social presence, and cognitive presence; and 2) the strength of class agreement on each of these. The class amount was measured by the mean score on each of the three scales (Cole et al., 2011b). This is referred to as the "aggregate class level" of each presence. The class consensus was measured by the standard deviation (SD) of the scale scores for teaching presence, social presence, and cognitive presence, multiplied by -1.0. The SD was chosen because it is a fairly robust measure of agreement (Roberson, Sturman, \& Simons, 2007), and it is frequently used as an index of attitude dispersion and its converse, agreement, in composition research (Cole et al., 2011a; Dineen et al., 2007; Ford \& Seers, 2006; Schneider et al., 2002). Multiplying the SD by 1 simplified interpretation and created an index of agreement rather than dispersion (Bliese \& Halverson, 1998; Cole \& Bedeian, 2007).

\section{Analyses and Results}

The means, SDs, and correlations among all study variables are presented in Table 2. The mean class level of teaching presence was correlated at .57 $(\mathrm{p}<.001)$ with the transformed (negative) SD of teaching presence, measuring agreement. 
Table 2

Descriptive Statistics and Intercorrelations Among Class Variables

\begin{tabular}{|c|c|c|c|c|c|c|c|c|c|c|}
\hline & Mean & $S D$ & $\begin{array}{l}\text { Tch Pres } \\
\text { Mean }\end{array}$ & $\begin{array}{l}\text { Cog Pres } \\
\text { Mean }\end{array}$ & $\begin{array}{l}\text { Socl Pres } \\
\text { Mean }\end{array}$ & $\begin{array}{l}\text { Tch Pres } \\
\text { Agrnt }\end{array}$ & $\begin{array}{l}\text { Cog Pres } \\
\text { Agrnt }\end{array}$ & $\begin{array}{l}\text { Socl Pres } \\
\text { Agrnt }\end{array}$ & $\begin{array}{c}\% \\
\text { Female }\end{array}$ & Avg Age \\
\hline $\begin{array}{l}\text { Teach Pres } \\
\text { Class Mean }\end{array}$ & 4.20 & .35 & & & & & & & & \\
\hline $\begin{array}{l}\text { Cog Pres Class } \\
\text { Mean }\end{array}$ & 4.15 & .27 & $\begin{array}{l}0.56 \\
* * *\end{array}$ & & & & & & & \\
\hline $\begin{array}{l}\text { Social Pres } \\
\text { Class Mean }\end{array}$ & 4.02 & .31 & $\begin{array}{c}0.29 \\
* *\end{array}$ & $\begin{array}{l}0.66 \\
* * *\end{array}$ & & & & & & \\
\hline $\begin{array}{l}\text { Teach Pres } \\
\text { Agreement }\end{array}$ & -.65 & .32 & $\begin{array}{l}0.57 \\
* * *\end{array}$ & $\stackrel{0.22}{*}$ & .00 & & & & & \\
\hline $\begin{array}{l}\text { Cog Pres } \\
\text { Agreement }\end{array}$ & -.54 & .23 & $\begin{array}{l}0.46 \\
* * *\end{array}$ & $\begin{array}{l}0.52 \\
* * *\end{array}$ & $\begin{array}{l}0.25 \\
* *\end{array}$ & $\begin{array}{l}0.57 \\
* * *\end{array}$ & & & & \\
\hline $\begin{array}{l}\text { Social Pres } \\
\text { Agreement }\end{array}$ & -.56 & .20 & $\begin{array}{c}0.19 \\
*\end{array}$ & $\begin{array}{l}0.31 \\
* * *\end{array}$ & $\begin{array}{l}0.42 \\
* * *\end{array}$ & .09 & $\begin{array}{l}0.39 \\
* * *\end{array}$ & & & \\
\hline $\begin{array}{l}\% \\
\text { Female }\end{array}$ & 65.47 & 20.22 & -.02 & .05 & .02 & .05 & .04 & .08 & & \\
\hline $\begin{array}{l}\text { Average } \\
\text { Age }\end{array}$ & 36.02 & 5.03 & -.12 & .11 & $\begin{array}{c}0.19 \\
*\end{array}$ & -.16 & -.02 & .10 & -.05 & \\
\hline $\begin{array}{l}\text { Avg Online } \\
\text { Courses Taken }\end{array}$ & 6.04 & 2.10 & -.15 & .13 & $\begin{array}{c}0.24 \\
* *\end{array}$ & $\begin{array}{c}-0.22 \\
*\end{array}$ & $\begin{array}{c}-0.19 \\
*\end{array}$ & .05 & -.02 & $\begin{array}{l}0.40 \\
* * *\end{array}$ \\
\hline
\end{tabular}

*** $\mathrm{p}<.001 ; * * \mathrm{p}<.01 ; * \mathrm{p}<.05 ; \# \mathrm{p} \leq .10$

$\mathrm{N}=126$ classes

Hypothesis 1 held that the higher the aggregate level of teaching presence and agreement among students in an online class, the higher the aggregate level of cognitive presence. Regression analysis was used to identify the independent effects of the aggregate level and agreement about teaching presence on the aggregate level of cognitive presence. The level of teaching presence, dummy coded to separate high and low levels, agreement (-SD for the class), and interaction were entered simultaneously along with a set of control variables: percent female in the class, average student age, and the average number of prior online classes taken. This process holds each predictive variable constant in assessing the effects of the others. Results are shown in Table 3. 
Table 3

Effect of Class Levels and Agreement about Teaching Presence on Levels of Cognitive and Social Presence

\begin{tabular}{|c|c|c|c|c|c|}
\hline Dependent Variable & & Std. Error & $\begin{array}{c}\text { Standardized } \\
\text { Beta }\end{array}$ & Adjusted $\mathrm{R}^{2}$ & Sig. \\
\hline \multirow[t]{8}{*}{$\begin{array}{l}\text { Cognitive Presence Level } \\
\text { (Class Mean) }\end{array}$} & (Constant) & 0.20 & & & $* * *$ \\
\hline & Percent Female & 0.00 & 0.09 & & \\
\hline & Average Age & 0.01 & 0.09 & & \\
\hline & Avg N Online Courses & 0.01 & 0.19 & & $*$ \\
\hline & Teach Pres Agreement & 0.10 & -0.08 & & \\
\hline & TP Mean & 0.12 & 0.85 & & *** \\
\hline & TP Mean x Agreement & 0.16 & 0.46 & & $*$ \\
\hline & & & & 0.21 & $* * *$ \\
\hline \multirow[t]{8}{*}{$\begin{array}{l}\text { Social Presence Level } \\
\text { (Class Mean) }\end{array}$} & (Constant) & 0.25 & & & $* * *$ \\
\hline & Percent Female & 0.00 & 0.05 & & \\
\hline & Average Age & 0.01 & 0.12 & & \\
\hline & Avg N Online Courses & 0.01 & 0.23 & & $*$ \\
\hline & Teach Pres Agreement & 0.12 & -0.08 & & \\
\hline & TP Mean & 0.15 & 0.36 & & $\#$ \\
\hline & TP Mean x Agreement & 0.20 & 0.15 & & \\
\hline & & & & 0.07 & $*$ \\
\hline
\end{tabular}

*** $\mathrm{p}<.001 ; * * \mathrm{p}<.01 ; * \mathrm{p}<.05 ; \# \mathrm{p} \leq .10$

$\mathrm{N}$ Classes $=126$

Hypothesis 1 was supported, because the regression predicted a significant amount of the variance in the mean levels of cognitive presence (adjusted $\mathrm{R}^{2}=0.21$, F Change $=$ $6.64, \mathrm{p}<.001)$. The dummy-coded mean level of teaching presence had a positive effect on the mean level of cognitive presence (beta $=0.85, \mathrm{p}<001$ ). The interaction between class agreement and level also had a significant effect (beta $=0.46, \mathrm{p}<.05$ ). This indicates that in classes with strong levels of teaching presence (TP Mean $=1$ ), the stronger the agreement, the higher the levels of cognitive presence. With this effect statistically held constant, the agreement on teaching presence only captures agreement in classes where teaching presence is low (TP Mean $=0$ ); the beta weight is negative indicating that stronger agreement leads to lower cognitive presence. However, the effect did not reach statistical significance. The overall effects of agreement about teaching presence on cognitive presence for classes with high versus low levels of 
teaching presence are shown in Figure 1. In addition, one of the control variables, the average number of prior online courses taken, significantly predicted cognitive presence (beta $=0.19, \mathrm{p}<.05)$.

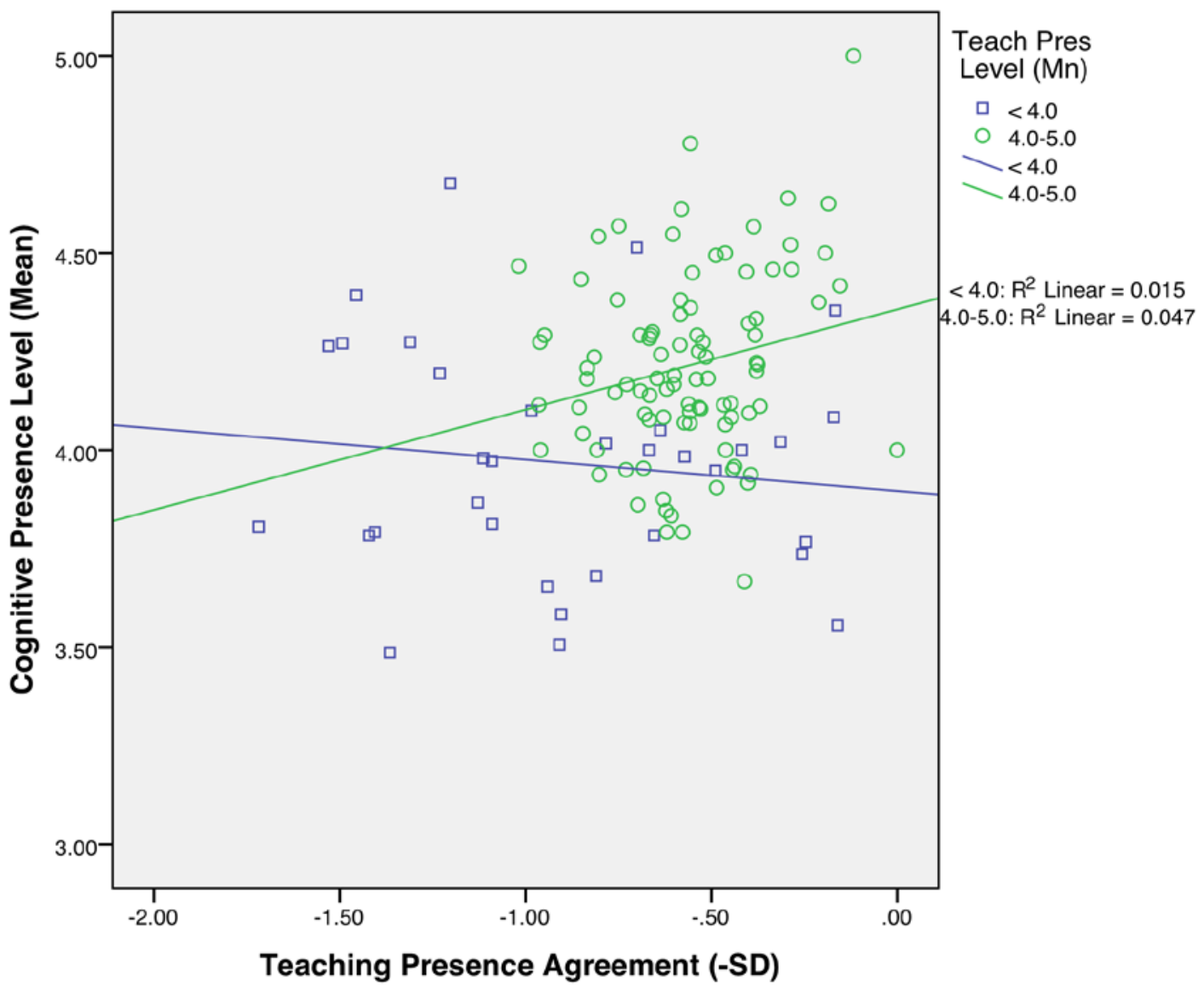

Figure 1. Effect of teaching presence agreement on cognitive presence level by teaching presence level.

Hypothesis 2 held that the higher the aggregate level of teaching presence and agreement among students in an online class, the higher the aggregate level of social presence. It was also tested with regression analysis, with the results presented in Table 3. Hypothesis 2 was partially supported; together the variables significantly predicted the mean level of social presence in online classes (adjusted $\mathrm{R}^{2}=0.07, \mathrm{~F}$ change $=2.49$, $\mathrm{p}<$.05). However, only one of the individual predictors was significant, and that only marginally: the dummy-coded class average of teaching presence had a marginally significant effect on the average level of social presence (beta $=0.36, \mathrm{p}=.10$ ). Agreement about teaching presence in classes with higher levels (TP Mean $\mathrm{x}$ Agreement) had a non-significant but positive effect (beta $=0.15$ ), indicating a trend in the predicted direction. The remaining variance predicted by agreement about teaching presence in classes with low levels of teaching presence had a negative effect (beta = - 
0.08), mirroring the findings for cognitive presence. The overall effect of agreement about teaching presence on class level of social presence, distinguishing between the relationships in classes with high versus low levels of teaching presence, is shown in Figure 2. The average number of online courses taken by the class members had the second strongest effect on social presence (beta $=0.23, \mathrm{p}<.05$ ), and the only statistically significant one.

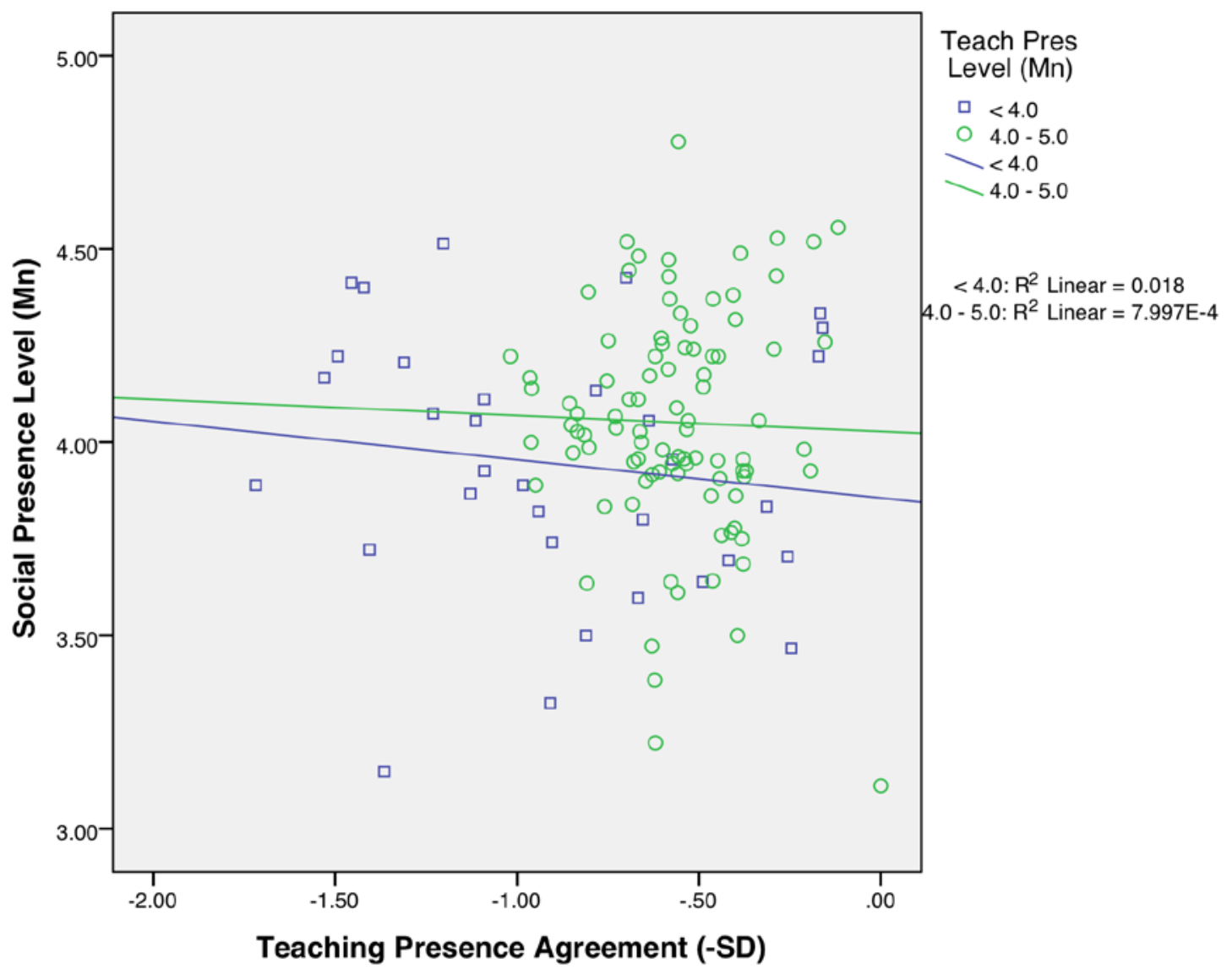

Figure 2. Effect of teaching presence agreement on social presence level by teaching presence level.

The remaining hypotheses focused on predicting class agreement rather than levels. Hypothesis 3 held that the higher the aggregate level of teaching presence and agreement among students in an online class at a given level, the higher the agreement about cognitive presence. This was tested with regression analyses that separately considered classes with high versus lower levels of cognitive presence, following Shea and Bidjerano (2009a) because of the different phenomena represented by agreement in classes with high levels as opposed to lower levels. Classes with an average level over 4 on cognitive presence $(n=91)$ were analyzed separately from classes with an average level between 3 and 4 ( $n=35)$; both results are presented in Table 4 . 
Hypothesis 3 was strongly supported; $23 \%$ of the agreement on cognitive presence in classes with strong levels of cognitive presence was predicted by the model $(R=0.53$, adjusted $\mathrm{R}^{2}=0.23, \mathrm{~F}=5.59, \mathrm{p}<.001$ ), and the effects were even strong in classes with low levels of cognitive presence $\left(\mathrm{R}=0.77\right.$, adjusted $\left.\mathrm{R}^{2}=0.50, \mathrm{~F}=6.61, \mathrm{p}<.001\right)$. The individual effects of teaching presence level and agreement were not as strong but had predicted trends. In classes with strong levels of cognitive presence, the average level of teaching presence had a positive but non-significant effect (beta $=0.26, \mathrm{p}=.26$ ). Agreement about teaching presence had a significant effect on agreement about cognitive presence both for classes with high teaching presence (beta $=0.48, \mathrm{p}<.05$ ) and for classes with low teaching presence $($ beta $=0.26, \mathrm{p}<.10$ ).

In classes with low levels of cognitive presence, the level of teaching presence had no effect on agreement about cognitive presence (beta $=-0.17, \mathrm{p}=.68$ ), while agreement about teaching presence had a very strong effect on agreement about cognitive presence (beta $=0.77, \mathrm{p}<.001$ ). In these classes, the average age of the students also had a positive effect on cognitive presence agreement (beta $=0.29, \mathrm{p}<.10$ ). The average number of prior online classes taken had a negative effect on cognitive presence agreement, although it was not significant (beta $=-0.22, \mathrm{p}=.16$ ). The more prior online classes students had taken, the less they agreed about cognitive presence in these classes with lower levels. 
Table 4

Effect of Class Teaching Presence on Agreement About Cognitive Presence

\begin{tabular}{|c|c|c|c|c|c|}
\hline Dependent Variable & & Std. Error & $\begin{array}{c}\text { Standardized } \\
\text { Beta }\end{array}$ & Adjusted $\mathrm{R}^{2}$ & Sig. \\
\hline \multirow{7}{*}{$\begin{array}{l}\text { Cognitive Presence Agreement } \\
\text { with High Levels (Class Mean } \\
\text { Between } 4 \text { and } 5 \text { ) } \\
(\mathrm{N}=91)\end{array}$} & (Constant) & 0.18 & & & $*$ \\
\hline & Percent Female & 0.00 & 0.02 & & \\
\hline & Average Age & 0.00 & 0.03 & & \\
\hline & Avg N Online classes & 0.01 & -0.05 & & \\
\hline & Teach Pres Mean & 0.11 & 0.26 & & \\
\hline & Teach Pres Agreement & 0.09 & 0.26 & & $\#$ \\
\hline & TP Mean x Agreement & 0.13 & 0.48 & & $*$ \\
\hline & & & & 0.23 & $* * *$ \\
\hline \multirow{8}{*}{$\begin{array}{l}\text { Cognitive Presence Agreement } \\
\text { with Low Levels (Class Mean } \\
\text { Below 4.0) } \\
(\mathrm{N}=35)\end{array}$} & (Constant) & 0.26 & & & $\#$ \\
\hline & Percent Female & 0.00 & -0.07 & & \\
\hline & Average Age & 0.01 & 0.29 & & $\#$ \\
\hline & Avg N Online classes & 0.02 & -0.22 & & \\
\hline & Teach Pres Mean & 0.23 & -0.17 & & \\
\hline & Teach Pres Agreement & 0.11 & 0.77 & & $* * *$ \\
\hline & TP Mean x Agreement & 0.35 & -0.08 & & \\
\hline & & & & 0.50 & $* * *$ \\
\hline
\end{tabular}

*** $\mathrm{p}<.001 ; * * \mathrm{p}<.01 ; * \mathrm{p}<.05 ; \# \mathrm{p} \leq .10$

$\mathrm{N}=126$

Hypothesis 4 held that the higher the aggregate level of teaching presence and agreement among students in an online class at a given level, the higher the agreement about social presence. Regression analyses were conducted separately on classes with high ( $\mathrm{n}=67$ ) and lower $(\mathrm{n}=59$ ) levels of social presence, again distinguished by mean scores over 4.0; results are presented in Table 5. This hypothesis was partially supported. For classes with higher levels of social presence, more than $15 \%$ of the variance in agreement was predicted $\left(\mathrm{R}=.48\right.$, adjusted $\left.\mathrm{R}^{2}=0.16, \mathrm{~F}=3.03, \mathrm{p}<.05\right)$. In classes with lower levels of social presence, about $8 \%$ of the variance on agreement was predicted, which is marginally significant $\left(R=0.42\right.$, adjusted $R^{2}=0.08, F=1.86, p=$ $.11)$. 
Table 5

Effect of Class Teaching Presence on Agreement About Social Presence

\begin{tabular}{|c|c|c|c|c|c|}
\hline Dependent Variable & & Std. Error & $\begin{array}{c}\text { Standardized } \\
\text { Beta }\end{array}$ & Adjusted $\mathrm{R}^{2}$ & Sig. \\
\hline \multirow{8}{*}{$\begin{array}{l}\text { Social Presence Agreement } \\
\text { with High Levels (Class Mean } \\
\text { Between } 4 \text { and 5) } \\
(\mathrm{N}=67)\end{array}$} & (Constant) & 0.19 & & & *** \\
\hline & Percent Female & 0.00 & 0.07 & & \\
\hline & Average Age & 0.00 & 0.04 & & \\
\hline & Avg $\mathrm{N}$ Online classes & 0.01 & 0.30 & & $*$ \\
\hline & Teach Pres Mean & 0.12 & 0.54 & & $\#$ \\
\hline & Teach Pres Agreement & 0.09 & -0.17 & & \\
\hline & TP Mean x Agreement & 0.14 & 0.76 & & $* *$ \\
\hline & & & & 0.16 & $*$ \\
\hline \multirow{8}{*}{$\begin{array}{l}\text { Social Presence Agreement } \\
\text { with Low Levels (Class Mean } \\
\text { Below 4.0) } \\
(\mathrm{N}=59 \text { ) }\end{array}$} & (Constant) & 0.25 & & & ** \\
\hline & Percent Female & 0.001 & 0.06 & & \\
\hline & Average Age & 0.01 & 0.24 & & \\
\hline & Avg N Online classes & 0.01 & -0.28 & & $\#$ \\
\hline & Teach Pres Mean & 0.14 & 0.41 & & \\
\hline & Teach Pres Agreement & 0.12 & 0.08 & & \\
\hline & TP Mean x Agreemt & 0.20 & 0.19 & & \\
\hline & & & & 0.08 & \\
\hline
\end{tabular}

$* * * \mathrm{p}<.001 ; * * \mathrm{p}<01 ; * \mathrm{p}<.05 ; \# \mathrm{p} . \leq 10$

$\mathrm{N}=126$

In classes with high levels of social presence, the level of teaching presence had a marginally significant effect on social presence agreement (beta $=0.54, p<.10$ ), and the agreement on teaching presence in classes with high levels, as measured by the interaction term, was highly significant (beta $=0.76, \mathrm{p}<.01$ ). Interestingly, the agreement on teaching presence on classes where its level was low, indicated by the beta weight for teaching presence agreement with the interaction term held constant, had a negative but non-significant effect (beta $=-0.17, \mathrm{p}=.32$ ). In addition, the number of prior online courses taken had a significant effect of increasing agreement on social presence (beta $=0.30, \mathrm{p}<.05)$.

In classes where the level of social presence was lower, neither the level nor agreement about teaching presence reached significance in predicting the agreement on social presence. The only marginally significant effect was found for the average number of prior online classes, which had a negative beta weight; the more prior online experience 
students had in classes with low levels of social presence, the less the agreement about social presence (beta $=-0.28, \mathrm{p}<.10$ ). With prior online experience held constant, average age approached significance in the other direction (beta $=0.24, \mathrm{p}=.12$ ). The overall formula was marginally significant (adjusted $\mathrm{R}^{2}=0.08, \mathrm{p}=.11$ ).

\section{Discussion}

This study examined the effect of teachers as leaders in online classes, focusing on their ability to create teaching presence and, through it, a strong and cohesive community of inquiry. It explored aspects of the CoI that are seldom studied: the effect of aggregated class-level perceptions of teaching presence, agreement about that level in the class, and the interaction of both class level and agreement in the online class community. It found that, much as effective leaders create both high levels and consensus among work groups (Bliese \& Halverson, 1998; Feinberg et al., 2005), effective teachers also create both high levels and consensus. Further, the average level and within-group agreement about teacher behavior have interactive effects on the class environment and outcomes (Cole et al., 2011a; Cole et al., 2011b; Dineen et al., 2007).

Overall, the average level of class perceptions of teaching presence were related to their agreement, and zero-order correlations indicated that the higher the level of teaching presence the class reported, the higher levels of cognitive presence and social presence the class reported, as well as more agreement about all three. Teaching presence was more closely related to cognitive presence than to social presence, consistent with some previous research (Shea et al., 2005). In addition, correlational analysis found no zeroorder relationship between the class agreement about teaching presence and either the class level or agreement about social presence. Of the control variables, only average age and prior online experience were related to the CoI; classes with older students were more likely to have higher levels of social presence, as were classes where students had more online experience. However, having more online experience was negatively associated with agreement about teaching and cognitive presence.

Hypotheses 1 and 2 examined the effects of teaching presence on the class levels of cognitive and social presence, and were supported by regression analysis. Both the aggregate level of teaching presence and interaction between the level and agreement about teaching presence predicted the level of cognitive presence in online classes. This indicates that when students agreed that a teacher was actively guiding learning in a well-structured class, it created more class engagement and application of the content. However, when teachers did not demonstrate much teaching presence, class agreement about their teaching reduced cognitive presence, although this negative beta weight was not statistically significant.

The effects of teaching presence on social presence levels were weaker, although still significant. When the class as a whole perceived their teacher as demonstrating 
presence, students communicated with and trusted one another more, although the effect was only marginally significant. The interaction between the level and agreement on teaching presence did not significantly affect social presence levels, although the trends were in the hypothesized directions: For courses where students reported many teaching behaviors, agreement about those high levels had a positive effect on social presence levels, while agreement about lower levels of teaching presence had a negative effect on social presence.

The effects of teaching presence on agreement among students about cognitive and social presence also were significant (Hypotheses 3 and 4), although again stronger for cognitive presence. In classes where students reported much engagement with course concepts, integrating and applying them to solve problems (high cognitive presence), agreement about the teacher's design and instructional guidance, particularly when students perceived them to be effective, led to strong agreement about critical engagement with the course content. However, when students did not engage extensively and deeply with the course materials (lower levels of cognitive presence) and they felt that teachers did not design or support courses well (low teaching presence), the amount of agreement about the lower levels of teaching strongly predicted agreement about the lower levels of cognitive engagement.

In classes where students reported high levels of social presence, both the level and the agreement about high levels of teaching presence (interaction term) predicted agreement about social presence. This indicates that in close-knit learning communities, the open communication and sharing of information among class members created stronger agreement among students about both the teaching presence and the connections they share, reflected in high levels and agreement about social presence (Bangert, 2008). However, this effect disappeared, and in fact became negative, although not significant, when teaching presence was low: In classes with strong social presence, if teachers did not actively support students (lower teaching presence), then agreement about the teacher's behavior predicted disagreement about social presence, although the effect was slight.

In classes where there was little social interaction and communication, on the other hand, the teacher did not seem to have much effect; neither the level nor agreement about teaching presence affected the agreement about social presence. The only factors that neared significance were personal attributes: In classes where students had less online experience, there was more agreement about the lower levels of social presence.

This supports the effect of both teachers and students on the online experience. For example, social and cognitive presence are affected by students' self-regulation, which Shea and Bidjerano $(2010,2012)$ have referred to as "student presence." Students also differ in their expectations and desires for interaction, and may respond differently to the same teaching behaviors (Swan \& Shih, 2005). For some students, active teacher guidance may be welcome and create more focus and deeper connection, while for others students it may be perceived as intrusive and produce resentment. The likelihood 
of students' perceiving and responding differently was supported by the strong effects of group demographics that were found on both the level and agreement about social and cognitive presence; average student age and, even more significantly, average experience with online classes increased the classes' social and cognitive presence. While prior research has examined individual student demographics (e.g., Kim et al., 2011; Shea \& Bidjerano, 2009b; Shea, Li, \& Pickett, 2006) little research has examined the effect of group demographics; this study supports that notion that the class composition affects the individual's experience.

Overall, it is evident that the causal effects of teaching presence on social and cognitive presence that have been found within individual students also exist at the aggregate or class level, supporting the concept of the teacher as class leader. However, the phenomena in online classes with high levels of learning community are different from those in classes with low levels, and class levels interact with agreement.

\section{Limitations of the Study and Future Research}

This study is limited by several factors. First, all data were collected in a single university, although different schools and pedagogical approaches were represented. However the majority were in an interdisciplinary program with a constructivist pedagogy and standardized courses. Nearly all students were adults, and the average levels of CoI were fairly high. All of these factors may limit the generalizability of the findings.

Future research should consider the effects of both the group level and the group agreement on the outcomes of online learning. For example, it might explore the effects of both class level and agreement on student satisfaction and learning in online classes, to identify the importance of peer agreement on individual student outcomes. Another promising area is the effects of agreement in online classes in different disciplines, extending the research that has found individual-level differences (Arbaugh, 2005; Arbaugh, Bangert, \& Cleveland-Innes, 2010).

\section{Conclusions}

This study examined the effect of shared group perceptions of teaching on other aspects of the CoI, considering separately the group level and agreement. It found that the previously supported effect of teaching presence on cognitive and social presence, as perceived by individuals, also exists at the aggregate or class level. However, when teachers do little to support learning, agreement is associated with negative effects on the learning community. Class composition, in terms of student age and experience with online learning, affects both social and cognitive engagement. The independent effect of class agreement on outcomes supports the notion that peers' perceptions, and in 
particular the strength of their agreement, can improve or hinder the learning environment; examining only the perceptions of individuals leaves out key aspects of the community. 


\section{References}

Akyol, Z., \& Garrison, D. R. (2011). Understanding cognitive presence in an online and blended community of inquiry: Assessing outcomes and processes for deep approaches to learning. British J ournal of Educational Technology, 42(2). doi: 10.1111.j.1467-8535.2009.01029.x

Anderson, T., Rourke, L., Garrison, D. R., \&Archer, W. (2001). Assessing teaching presence in a computer conferencing context. J ournal of Asynchronous Learning Networks, 5(2).

Arbaugh, J . B. (2005). How much does "subject matter" matter? A study of disciplinary effects in on-line MBA courses. Academy of Management Learning \& Education, 4(1), 57-73. doi: 10.5465/amle.2005.16132549

Arbaugh, J . B. (2007). An empirical verification of the community of inquiry framework. J ournal of Asynchronous Learning Networks, 11(1), 73-84.

Arbaugh, J . B., Bangert, A., \& Cleveland-Innes, M. (2010). Subject matter effects and the community of inquiry (CoI) framework: An exploratory study. The Internet and Higher Education, 13(1-2), 37-44. doi: 10.1016/j.iheduc.2009.10.006

Bangert, A. (2008). The influence of social presence and teaching presence on the quality of online critical inquiry. J ournal of Computing in Higher Education, 20(1), 34-61. doi: 10.1007/ bf03033431

Biemann, T., Cole, M. S., \& Voelpel, S. (2012). Within-group agreement: On the use (and misuse) of rWG and rWG(J) in leadership research and some best practice guidelines. The Leadership Quarterly, 23(1), 66-80. doi: 10.1016/j.leaqua.2011.11.006

Bliese, P. D., \& Halverson, R. R. (1998). Group consensus and psychological well-being: A large field study. J ournal of Applied Social Psychology, 28(7), 563-580. doi: 10.1111/j.1559-1816.1998.tb01720.x

Cole, M. S., \& Bedeian, A. G. (2007). Leadership consensus as a cross-level contextual moderator of the emotional exhaustion-work commitment relationship. The Leadership Quarterly, 18(5), 447-462. doi: http:// dx.doi.org/ 10.1016/j.leaqua.2007.07.002

Cole, M. S., Bedeian, A. G., \&Bruch, H. (2011a). Linking leader behavior and leadership consensus to team performance: Integrating direct consensus and dispersion models of group composition. The Leadership Quarterly, 22(2), 383-398. doi: http:// dx.doi.org/ 10.1016/j.leaqua.2011.02.012 
Cole, M. S., Bedeian, A. G., Hirschfeld, R. R., \&Vogel, B. (2011b). Dispersioncomposition models in multilevel research: A data-analytic framework. Organizational Research Methods, 14(4), 718-734. doi: 10.1177/ 1094428110389078

Conway, N., \& Briner, R. B. (2012). Investigating the effect of collective organizational commitment on unit-level performance and absence. J ournal of Occupational and Organizational Psychology, 85(3), 472-486. doi: 10.1111/j.20448325.2011.02051.x

Dineen, B. R., Noe, R. A., Shaw, J . D., Duffy, M. K., \& Wiethoff, C. (2007). Level and dispersion of satisfaction in teams: Using foci and social context to explain the satisfaction-absenteeism relationship. Academy of Management J ournal, 50(3), 623-643. doi: 10.5465/ amj.2007.25525987

Dragoni, L. (2005). Understanding the emergence of state goal orientation in organizational work groups: The role of leadership and multilevel climate perceptions. The J ournal of Applied Psychology, 90(6), 1084-1095.

Feinberg, B. J., Ostroff, C., \& Burke, W. W. (2005). The role of within-group agreement in understanding transformational leadership. J ournal of Occupational and Organizational Psychology, 78, 471-488.

Ford, L. R., \& Seers, A. (2006). Relational leadership and team climates: Pitting differentiation versus agreement. The Leadership Quarterly, 17(3), 258-270. doi: 10.1016/j.leaqua.2006.02.005

Garrison, D. R., Anderson, T., \&Archer, W. (2000). Critical inquiry in a text-based environment: Computer conferencing in higher education. The Internet and Higher Education, 2(2- 3), 87-105. doi: 10.1016/s1096-7516(00)00016-6

Garrison, D. R., Anderson, T., \&Archer, W. (2010a). The first decade of the community of inquiry framework: A retrospective. The Internet and Higher Education, 13(1-2), 5-9. doi: 10.1016/j.iheduc.2009.10.003

Garrison, D. R., \& Cleveland-Innes, M. (2005). Facilitating cognitive presence in online learning: Interaction is not enough. The American J ournal of Distance Education, 19(3), 133-148.

Garrison, D. R., Cleveland-Innes, M., \& Fung, T. S. (2010b). Exploring causal relationships among teaching, cognitive and social presence: Student perceptions of the community of inquiry framework. The Internet and Higher Education, 13(1-2), 31-36. doi: http:// dx.doi.org/ 10.1016/j.iheduc.2009.10.002 
Gillespie, T. L., \& Parry, R. O. (2009). Students as employees: Applying performance management principles in the management classroom. J ournal of Management Education, 33(5), 553-576. doi: 10.1177/ 1052562908315334

Glisson, C., \&J ames, L. R. (2002). The cross-level effects of culture and climate in human service teams. J ournal of Organizational Behavior, 23(6), 767-794. doi: 10.1002/job.162

González-Romá, V., Peiró, J . M., \&Tordera, N. (2002). An examination of the antecedents and moderator influences of climate strength. J ournal of Applied Psychology, 87(3), 465-473. doi: 10.1037/ 0021-9010.87.3.465

J oo, Y. J ., Lim, K. Y., \& Kim, E. K. (2011). Online university students' satisfaction and persistence: Examining perceived level of presence, usefulness and ease of use as predictors in a structural model. Computers \& Education, 57(2), 1654-1664.

Kanuka, H., \& Garrison, D. (2004). Cognitive presence in online learning. J ournal of Computing in Higher Education, 15(2), 21-39. doi: 10.1007/ bf02940928

Ke, F. (2010). Examining online teaching, cognitive, and social presence for adult students. Computers \& Education, 55(2), 808-820. doi: 10.1016/j.compedu.2010.03.013

Kim, J ., Kwon, Y., \& Cho, D. (2011). Investigating factors that influence social presence and learning outcomes in distance higher education. Computers \& Education, 57(2), 1512-1520.

Kozlowski, S. W., \& Doherty, M. L. (1989). Integration of climate and leadership: Examination of a neglected issue. J ournal of Applied Psychology, 74(4), 546553. doi: $10.1037 / 0021-9010.74 .4 .546$

Kunter, M., Baumert, J ., \& Köller, O. (2007). Effective classroom management and the development of subject-related interest. Learning and Instruction, 17(5), 494509. doi: http://dx.doi.org/10.1016/j.learninstruc.2007.09.002

LeBreton, J . M., \& Senter, J . L. (2008). Answers to 20 questions about interrater reliability and interrater agreement. Organizational Research Methods, 11(4), 815-852. doi: 10.1177/ 1094428106296642

Lindell, M. K., \&Brandt, C. J . (2000). Climate quality and climate consensus as mediators of the relationship between organizational antecedents and outcomes. J ournal of Applied Psychology, 85(3), 331-348. doi: 10.1037/00219010.85.3.331

Lüdtke, O., Trautwein, U., Kunter, M., \& Baumert, J . (2006). Reliability and agreement of student ratings of the classroom environment: A reanalysis of TIMSS data. 
Learning Environments Research, 9(3), 215-230. doi: 10.1007/s10984-0069014-8

Luke, T. (1997). Discourse and discipline in the digital domain: The political economy of the virtual university. Paper presented at the Virtual Technologies in Tertiary Education: A Vision for New Zealand.

Pounder, J . S. (2008). Transformational classroom leadership: A novel approach to evaluating classroom performance. Assessment \& Evaluation in Higher Education, 33(3), 233-243. doi: 10.1080/02602930701292621

Richardson, J . C., \& Ice, P. (2010). Investigating students' level of critical thinking across instructional strategies in online discussions. The Internet and Higher Education, 13(1-2), 52-59. doi: 10.1016/j.iheduc.2009.10.009

Richardson, J . C., \& Swan, K. (2003). Examining social presence in online courses in relation to students' perceived learning and satisfaction. J ournal of Asynchronous Learning Networks, 7(1), 68-88.

Roberson, Q. M., Sturman, M. C., \& Simons, T. L. (2007). Does the measure of dispersion matter in multilevel research? A comparison of the relative performance of dispersion indexes. Organizational Research Methods, 10(4), 564-588. doi: 10.1177/ 1094428106294746

Rourke, L., Anderson, T., Garrison, D. R., \&Archer, W. (1999). Assessing social presence in asynchronous text-based computer conferencing. J ournal of Distance Education, 14(2), 50-71.

Rourke, L., \& Kanuka, H. (2007). Barriers to online critical discourse. International J ournal of Computer-Supported Collaborative Learning, 2(1), 105-126. doi: 10.1007/ s11412-007-9007-3

Rovai, A. P. (2007). Facilitating online discussions effectively. The Internet and Higher Education, 10(1), 77-88. doi: 10.1016/j.iheduc.2006.10.001

Schneider, B., \& Reichers, A. E. (1983). On the etiology of climates. Personnel Psychology, 36(1), 19-39.

Schneider, B., Salvaggio, A. N., \& Subirats, M. (2002). Climate strength: A new direction for climate research. J ournal of Applied Psychology, 87(2), 220-229. doi: 10.1037/ 0021-9010.87.2.220

Schneider, B., White, S., \& Paul, M. C. (1998). Linking service climate and customer perceptions of service quality: Tests of a causal model. J ournal of Applied Psychology, 83(2), 150-163. doi: 10.1037/ 0021-9010.83.2.150 
Shea, P., \& Bidjerano, T. (2009a). Cognitive presence and online learner engagement: A cluster analysis of the community of inquiry framework. J ournal of Computing in Higher Education, 21(3), 199-217. doi: 10.1007/ s12528-009-9024-5

Shea, P., \& Bidjerano, T. (2009b). Community of inquiry as a theoretical framework to foster "epistemic engagement" and "cognitive presence" in online education. Computers \&Education, 52(3), 543-553. doi: 10.1016/j.compedu.2008.10.007

Shea, P., \& Bidjerano, T. (2010). Learning presence: Towards a theory of self-efficacy, self-regulation, and the development of a communities of inquiry in online and blended learning environments. Computers \& Education, 55(4), 1721-1731. doi: 10.1016/j.compedu.2010.07.017

Shea, P., \& Bidjerano, T. (2012). Learning presence as a moderator in the community of inquiry model. Computers \&Education, 59(2), 316-326. doi:

10.1016/j.compedu.2012.01.011

Shea, P., Hayes, S., Vickers, J ., Gozza-Cohen, M., Uzuner, S., Mehta, R., . . Rangan, P. (2010). A re-examination of the community of inquiry framework: Social network and content analysis. The Internet and Higher Education, 13(1-2), 1021. doi: 10.1016/j.iheduc.2009.11.002

Shea, P., Li, C. S., \& Pickett, A. M. (2006). A study of teaching presence and student sense of learning community in fully online and web-enhanced college courses. The Internet and Higher Education, 9(3), 175-190. doi:

10.1016/j.iheduc.2006.06.005

Shea, P., Li, C. S., Swan, K., \& Pickett, A. (2005). Developing learning community in online asynchronous college courses: The role of teaching presence. J ournal of Asynchronous Learning Networks, 9(4), 59-82.

Swan, K. (2004). Relationships between interactions and learning in online environments. The Sloan Consortium.

Swan, K., Richardson, J . C., Ice, P., Garrison, D. R., Cleveland-Innes, M., \&Arbaugh, J . B. (2008). Validating a measurement tool of presence in online Communities of Inquiry. E-Mentor, 2(24).

Swan, K., \& Shih, L. F. (2005). On the nature and development of social presence in online course discussions. J ournal of Asynchronous Learning Networks, 9(3), 115-136.

Zohar, D., \&Luria, G. (2005). A multilevel model of safety climate: Cross-level relationships between organization and group-level climates. J ournal of Applied Psychology, 90(4), 616-628. doi: 10.1037/ 0021-9010.90.4.616 
Zohar, D., \& Luria, G. (2010). Group leaders as gatekeepers: Testing safety climate variations across levels of analysis. Applied Psychology: An International Review, 59(4), 647-673. doi: 10.1111/j.1464-0597.2010.00421.x

\section{Athabasca University $\mathbf{a}$}

(c)

